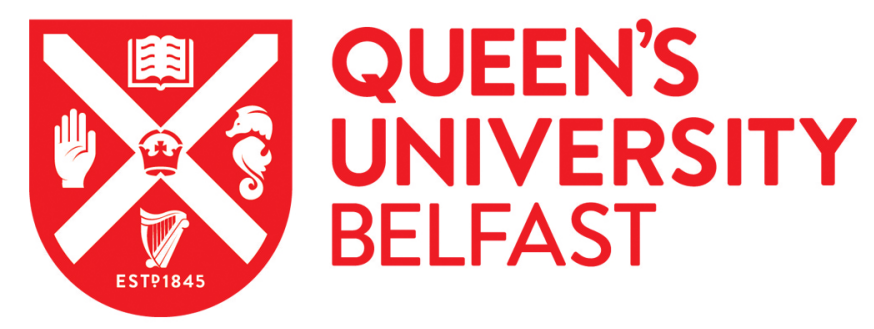

\title{
Enhanced dissipation of phenanthrene in spiked soil by arbuscular mycorrhizal alfalfa combined with a non-ionic surfactant amendment
}

Wu, N. Y., Zhang, S. Z., Huang, H. L., \& Christie, P. (2008). Enhanced dissipation of phenanthrene in spiked soil by arbuscular mycorrhizal alfalfa combined with a non-ionic surfactant amendment. Science of the Total Environment, 394(2-3), 230-236. https://doi.org/10.1016/j.scitotenv.2008.02.003

Published in:

Science of the Total Environment

Queen's University Belfast - Research Portal:

Link to publication record in Queen's University Belfast Research Portal

\section{General rights}

Copyright for the publications made accessible via the Queen's University Belfast Research Portal is retained by the author(s) and / or other copyright owners and it is a condition of accessing these publications that users recognise and abide by the legal requirements associated with these rights.

Take down policy

The Research Portal is Queen's institutional repository that provides access to Queen's research output. Every effort has been made to ensure that content in the Research Portal does not infringe any person's rights, or applicable UK laws. If you discover content in the Research Portal that you believe breaches copyright or violates any law, please contact openaccess@qub.ac.uk. 


\title{
Enhanced dissipation of phenanthrene in spiked soil by arbuscular mycorrhizal alfalfa combined with a non-ionic surfactant amendment
}

\author{
Naiying $\mathrm{Wu}^{a}$, Shuzhen Zhang ${ }^{a, *}$, Honglin Huang ${ }^{a}$, Peter Christie ${ }^{b}$ \\ aState Key Laboratory of Environmental Chemistry and Ecotoxicology, Research Center for Eco-Environmental Sciences, \\ Chinese Academy of Sciences, PO Box 2871, Beijing 100085, China \\ 'Queen's University Belfast, Agricultural and Environmental Science Department, Newforge Lane, Belfast BT9 5PX, UK
}

\section{A R T I C L E I N F O}

\section{Article history:}

Received 22 October 2007

Received in revised form

29 January 2008

Accepted 3 February 2008

Available online 7 March 2008

\section{Keywords:}

Phytoremediation

Alfalfa

Phenanthrene

Glomus etunicatum

Triton X-100

PLFA

\begin{abstract}
A B S T R A C T
Experiments were conducted to assess the role of colonization of alfalfa roots by an arbuscular mycorrhizal (AM) fungus (Glomus etunicatum) in conjunction with a non-ionic surfactant (Triton X-100) in dissipation of phenanthrene in a soil spiked with phenanthrene at $0,2.5,5.0$ and $10.0 \mathrm{mg} \mathrm{kg}^{-1}$. After plant harvest the residual phenanthrene concentration in the soil decreased markedly. Mycorrhizal treatment enhanced phenanthrene dissipation in the rhizosphere and bulk soils irrespective of phenanthrene application rate. Addition of Triton X-100 resulted in the highest phenanthrene concentration in the rhizosphere soil among the treatments, while the lowest phenanthrene concentration in the bulk soil was obtained by AM inoculation and amendment with Triton X-100. AM inoculation and addition of the surfactant consistently promoted phenanthrene dissipation in the soil and decreased the microbial biomass based on phospholipid fatty acid (PLFA) analysis. PLFA profiles demonstrated that AM inoculation together with addition of Triton X-100 altered the microbial community structure in the rhizosphere soil. The results of this study provide a reference value for phytoremediation of soil contaminated by organic pollutants.
\end{abstract}

(C) 2008 Elsevier B.V. All rights reserved.

\section{Introduction}

Polycyclic aromatic hydrocarbons (PAHs) are widely distributed hydrophobic organic contaminants (HOCs) and accumulate in soil that has been contaminated with crude oil, creosote, or coal tar. PAHs are also generated and dispersed into the environment by fossil fuel combustion, wood treatment processes, automobile exhausts, and waste incineration (Wilson and Jones, 1993). Because of their widespread distribution and their toxicity and mutagenicity, PAHs are listed as priority pollutants, and remediation of soils contaminated with PAHs is of great importance.

Phytoremediation is a promising alternative approach to soil remediation due to its convenience, cost-effectiveness and environmental acceptability. The HOCs in soil usually exhibit low bioavailability to both microorganisms and plants due to their strong affinity to the soil matrix, especially to soil organic matter (Chen et al., 2005), which limits the application of phytoremediation. Solubilization agents such as the surfactant Triton X-100 have been added to soil to enhance the release of HOCs from the sorbed phase and, thereby, to increase their aqueous concentrations and bioavailability (Zhou and Zhu, 2005). Although addition of surfactants has been explored in the cleanup of contaminated soils (Zhu et al., 2003), there are few reports of their application in phytoremediation.

Arbuscular mycorrhiza (AM) is a ubiquitous association between soil fungi and the roots of most herbaceous plant

\footnotetext{
* Corresponding author. Tel.: +86 10 62849683; fax: +861062923563.

E-mail address: szzhang@rcees.ac.cn (S. Zhang).
} 
species that permits the host plant to exploit nutrients in the soil beyond the rhizosphere through fungal transport (Joner and Leyval, 2003). Mycorrhizal colonization can result in quantitative and qualitative changes in root exudation and in the soil microbial community, particularly in the rhizosphere. We hypothesized that the effects of AM fungi on soil phytoremediation would be enhanced by the application of a surfactant to the soil due to the enhanced mobility of organic pollutants. We would also expect increased PAH degradation and plant establishment on contaminated sites in the presence of mycorrhizal fungi as well as increased resistance to potentially phytotoxic effects of the surfactant. Despite the potential role of AM in the phytoremediation of soils with organic contaminants, very few studies have been carried out on interactions between $\mathrm{AM}$ and organic pollutants such as PAHs in soil and variable results have been obtained. Positive effects of AM on the dissipation of PAHs in soils have been observed by Joner et al. (Joner and Leyval, 2003; Joner et al., 2001). In contrast, no impact of AM fungi on $\mathrm{PAH}$ dissipation was observed by Binet et al. (2000) and a depression in PAH dissipation was observed in the presence of ectomycorrhizas (Joner et al., 2006; Genney et al., 2004).

The objective of the present work was therefore to investigate the effect of arbuscular mycorrhiza, with or without the application of the non-ionic surfactant Triton X100 , on the dissipation of phenanthrene in a soil that was artificially contaminated with various levels of phenanthrene. The soil microbial community was characterized in order to understand the influence of AM inoculation and Triton X-100 application on the soil microbial community. The aim was to evaluate the potential value of AM inoculation combined with surfactant application to soil in the phytoremediation of organic pollutants.

\section{Materials and methods}

\subsection{Soil preparation and experimental design}

A loamy soil collected from the surface horizon $(0-15 \mathrm{~cm}$ depth) of an experimental field at the Beijing Academy of Agriculture and Forest Sciences was air-dried, ground and passed through a 2-mm nylon sieve. Selected soil properties were as follows: silt, 45\%; clay, 23\%; sand, 32\%; pH, 7.37 (1:2, soil/water); organic matter, 3.11\%; $\mathrm{NaHCO}_{3}$-extractable $\mathrm{P}$, $4.5 \mathrm{mg} \mathrm{kg}{ }^{-1}$; $\mathrm{C} / \mathrm{N}$ ratio, 8.1; cation exchange capacity, $25.0 \mathrm{cmol} \mathrm{kg}^{-1}$; and an initial phenanthrene concentration of $0.15 \mathrm{mg} \mathrm{kg}^{-1}$. Soil was mixed with sand $(1-2 \mathrm{~mm})$ at a ratio of $1: 1(\mathrm{w} / \mathrm{w})$ to produce the growth medium. The soil mixture (henceforth referred to as the soil) was sterilized by $\gamma$ radiation (10 kGy, $10 \mathrm{MeV} \gamma$ rays) to inactivate $\mathrm{AM}$ fungi and received mineral nutrients at rates of $30 \mathrm{mg} \mathrm{P}\left(\mathrm{KH}_{2} \mathrm{PO}_{4}\right), 60 \mathrm{mg}$ $\mathrm{N}\left(\mathrm{NH}_{4} \mathrm{NO}_{3}\right)$, and $67 \mathrm{mg} \mathrm{K}\left(\mathrm{K}_{2} \mathrm{SO}_{4}\right) / \mathrm{kg}$ soil. It was then artificially spiked with phenanthrene (Sigma Chemical Co. with a purity of $96 \%$ ) in acetone to produce initial concentrations of $0,2.5$, 5.0 and $10.0 \mathrm{mg} \mathrm{kg}^{-1}$ in soil. The spiked soils were mixed with uncontaminated soil and thoroughly mixed and incubated for four weeks at room temperature. The final concentrations of phenanthrene in the spiked soils were measured before planting and were $0.37,2.44,4.05$ and $9.46 \mathrm{mg} \mathrm{kg}^{-1}$, respectively. The experimental design consisted of four treatments: inoculation with sterilized inoculum (non-mycorrhizal), inoculation with viable inoculum (mycorrhizal), amendment with non-ionic surfactant, and amendment with viable mycorrhizal inoculum plus non-ionic surfactant. All treatments were set up in triplicate.

\subsection{Inoculum and host plants}

Inoculum of the AM fungus Glomus etunicatum (BGC USA01) was propagated for 10 weeks in pot culture on broomcorn (Sorghum vulgare Pers.) plants grown in a soil-sand mixture in a greenhouse. The inoculum, which was air-dried and passed through a 2-mm sieve, consisted of spores, mycelium, sandy soil and root fragments containing approximately 3500 spores /g soil (dry weight basis).

Alfalfa seeds (Medicago sativa L.) were purchased from the Chinese Academy of Agricultural Sciences, Beijing, China. They were surface sterilized in a $10 \%$ (v/v) solution of hydrogen peroxide for $10 \mathrm{~min}$, followed by thorough rinsing with sterile distilled water and pre-germinated on moist filter paper overnight. Seedlings of uniform size were selected and were ready for sowing.

\subsection{Pot experiment}

Treated soils (650 g dry weight soil per pot) were then placed in plastic pots and equilibrated in a greenhouse for 4 days at $70 \%$ of water holding capacity before the alfalfa seedlings were transplanted. Seven seedlings were planted in each pot and thinned to five seedlings after growth for 7 days. Pots with mycorrhizal treatments were inoculated by mixing $50 \mathrm{~g}$ of the fungal inoculum with about $200 \mathrm{~g}$ of soil and then placing the mixture in the middle layer of the pots. Non-mycorrhizal treatments received an equivalent amount of sterilized soilsand mixture. The opening of each pot was covered with a black bag to minimize the growth of algae and the upper 2$5 \mathrm{~mm}$ was covered with non-spiked sterilized soil to minimize the risk of loss of phenanthrene due to evaporation. In the case of the surfactant treatments, soils were amended with Triton X-100 after sowing to give a concentration of $0.1 \%$ (w/w). The pots were positioned randomly in a growth chamber and re-randomized every 2 days. Plants were maintained in a controlled-environment growth chamber with a photoperiod of $14 \mathrm{~h}$ at a light intensity of $250 \mu \mathrm{mol} / \mathrm{m}^{2} / \mathrm{s}$ provided by supplementary illumination, at $25^{\circ} \mathrm{C} / 20^{\circ} \mathrm{C}$ day/night temperature and relative humidity of $70 \%$. Distilled water was added as required to maintain moisture content at $70 \%$ of water holding capacity by regular weighing. Nitrogen fertilizer (as $\mathrm{NH}_{4} \mathrm{NO}_{3}$ ) was added to each pot 30 and 45 days after sowing to provide a total of $120 \mathrm{mg} \mathrm{N}$ per pot.

\subsection{Sample preparation}

Soils were destructively sampled 60 days after sowing. The upper 2-5 mm of soil in each pot was discarded. The bulk soils were collected by gently crushing the soil and shaking the roots. Soil that required repeated vigorous rubbing and shaking of the root system was classified as rhizosphere soil. 
Soil was manually homogenized and all the soil samples were stored at $4{ }^{\circ} \mathrm{C}$.

Shoots and roots were harvested separately. Root fragments were collected by sieving the soil and adding them to the root samples. Roots were first carefully washed with tap water to remove any adhering soil particles. Roots and shoots were then rinsed thoroughly with distilled water and blotted dry. A portion of fresh root sub-sample was taken from each treatment for the determination of the percentage of root length colonized by AM. Fresh weight and freeze-dried weight of all shoot and root samples were recorded. Some freezedried plant samples were weighed, oven dried at $105{ }^{\circ} \mathrm{C}$ for $24 \mathrm{~h}$ and re-weighed, and the differences between the ovendried weights and the freeze-dried weights were found to be negligible.

\subsection{Assessment of AM colonization of alfalfa roots}

The proportion of total root length colonized by the AM fungus was assessed by cutting a random sub-sample of $1 \mathrm{~g}$ fresh roots into 0.5 - to $1.0-\mathrm{cm}$-long segments. Root segments were cleared in $10 \% \mathrm{KOH}$ for $10 \mathrm{~min}$ at $90{ }^{\circ} \mathrm{C}$ in a water bath, rinsed in water, and then stained with $0.1 \%$ Trypan blue for 3-5 min at $90{ }^{\circ} \mathrm{C}$ in a water bath. Mycorrhizal colonization was determined by the grid line intersect method (Giovannetti and Mosse, 1980).

\subsection{Analysis of phenanthrene in soil}

One gram of soil sample was homogeneously mixed with an equivalent quantity of anhydrous $\mathrm{Na}_{2} \mathrm{SO}_{4}$ and was subjected to Soxhlet extraction with $100 \mathrm{ml}$ dichloromethane/acetone mixture (1:1, v/v) for $24 \mathrm{~h}$. The solvents were then evaporated, followed by passing through a column packed with $2 \mathrm{~g}$ of silica gel with $15 \mathrm{ml}$ of 1:1 (v/v) elution of hexane and dichloromethane. The eluates were then evaporated and exchanged with methanol prior to injection. The recovery obtained by spiking soil with phenanthrene was 93.2-105.1\% $\quad(n=5$, $\mathrm{RSD}<1.70 \%$ ) for the entire procedure.

The concentrations of phenanthrene were determined using a reverse-phase HPLC $\left(C_{18}\right.$ column, $4.6 \mathrm{~mm} \times 25 \mathrm{~cm}$, Agilent Technologies, Wilmington, USA) with a UV detector. The mobile phase was methanol: water (9:1, v/v) with a flow rate of $1 \mathrm{ml} / \mathrm{min}$. Under the HPLC conditions described phenanthrene showed a single peak at the retention time of $3.9 \mathrm{~min}$.

Table 1 - Mean shoot and root dry matter yield (freeze-dried basis) and proportion of root length colonized by the AM fungus after cultivation of mycorrhizal alfalfa with or without surfactant and non-mycorrhizal controls in soil containing different levels of added phenanthrene ${ }^{a}$ (mean $\pm S E, n=3$ )

Initial phenanthrene addition $\quad$ Treatment $\quad$ Shoot weight (g) Root weight (g) Mycorrhizal colonization ${ }^{\mathrm{b}}(\%)$ $\mathrm{mg} \mathrm{kg}^{-1}$

\begin{tabular}{|c|c|c|c|c|}
\hline \multirow[t]{4}{*}{0} & Non-mycorrhizal & $0.96 \pm 0.22 \mathrm{a}$ & $0.42 \pm 0.02 \mathrm{e}$ & 0 \\
\hline & Mycorrhizal & $0.76 \pm 0.02 b c$ & $0.32 \pm 0.04 \mathrm{ab}$ & $69.9 \pm 1.0 \mathrm{a}$ \\
\hline & Surfactant & $0.82 \pm 0.03 \mathrm{bcd}$ & $0.54 \pm 0.02 f$ & 0 \\
\hline & Mycorrhizal+surfactant & $0.66 \pm 0.04 d$ & $0.45 \pm 0.07 \mathrm{cde}$ & $64.9 \pm 4.8 a$ \\
\hline \multirow[t]{4}{*}{2.5} & Non-mycorrhizal & $0.90 \pm 0.04 \mathrm{ab}$ & $0.40 \pm 0.02 e$ & 0 \\
\hline & Mycorrhizal & $0.71 \pm 0.06 b c$ & $0.32 \pm 0.04 \mathrm{ab}$ & $69.4 \pm 2.7 \mathrm{~cd}$ \\
\hline & Surfactant & $0.83 \pm 0.02 c d$ & $0.57 \pm 0.03 f$ & 0 \\
\hline & Mycorrhizal+surfactant & $0.76 \pm 0.04 \mathrm{bcd}$ & $0.60 \pm 0.08 a$ & $59.3 \pm 3.3 \mathrm{de}$ \\
\hline \multirow[t]{4}{*}{5.0} & Non-mycorrhizal & $0.81 \pm 0.04 b c$ & $0.44 \pm 0.01 \mathrm{cde}$ & 0 \\
\hline & Mycorrhizal & $0.77 \pm 0.09 c d$ & $0.42 \pm 0.03 \mathrm{bcd}$ & $56.1 \pm 3.2 b$ \\
\hline & Surfactant & $0.73 \pm 0.11 \mathrm{bcd}$ & $0.50 \pm 0.03 \mathrm{de}$ & 0 \\
\hline & Mycorrhizal+surfactant & $0.72 \pm 0.07 c d$ & $0.51 \pm 0.02 b c$ & $51.5 \pm 0.9 c$ \\
\hline \multirow[t]{4}{*}{10.0} & Non-mycorrhizal & $0.81 \pm 0.10 b c$ & $0.44 \pm 0.01 \mathrm{cde}$ & 0 \\
\hline & Mycorrhizal & $0.82 \pm 0.11 b c d$ & $0.44 \pm 0.02 \mathrm{bcde}$ & $52.7 \pm 0.2 \mathrm{e}$ \\
\hline & Surfactant & $0.78 \pm 0.12 b c$ & $0.49 \pm 0.19$ cde & 0 \\
\hline & Mycorrhizal+surfactant & $0.75 \pm 0.08 c d$ & $0.61 \pm 0.01 \mathrm{a}$ & $51.0 \pm 2.2 \mathrm{e}$ \\
\hline \multicolumn{5}{|c|}{ Significance of: } \\
\hline \multicolumn{2}{|c|}{ Phenanthrene level } & n.s. & * & $* * *$ \\
\hline \multicolumn{2}{|c|}{ Inoculation } & $* * *$ & n.s & $* * *$ \\
\hline \multicolumn{2}{|c|}{ Surfactant } & ** & $* * *$ & * \\
\hline \multicolumn{2}{|c|}{ Phenanthrene level $\times$ inoculation } & * & $* *$ & $* * *$ \\
\hline \multicolumn{2}{|c|}{ Phenanthrene level $\times$ surfactant } & n.s. & $* *$ & n.s. \\
\hline \multicolumn{2}{|c|}{ Inoculation $\times$ surfactant } & n.s. & * & * \\
\hline \multicolumn{2}{|c|}{ Phenanthrene level $\times$ inoculation $\times$ surfactant } & n.s. & n.s. & n.s. \\
\hline
\end{tabular}

\footnotetext{
**** Significant effect at $p<0.001$.

${ }^{* *}$ Significant effect at $p<0.01$.

${ }^{*}$ Significant effect at $p<0.05$.

n.s., not significant.

a Means within each column with the same letter are not significantly different at the $5 \%$ level.

b Colonization of non-mycorrhizal plants was $0 \%$ and the data were therefore excluded from statistical analysis of the effects of phenanthrene/ surfactant on mycorrhizal colonization.
} 


\subsection{Analysis of phospholipid fatty acids in rhizosphere \\ soil}

Four grams of freeze-dried rhizosphere soil sample from each pot was extracted with $15.2 \mathrm{ml}$ of a mixture of phosphate buffer $(0.1 \mathrm{~mol} / \mathrm{l}, \mathrm{pH}=7)$, chloroform and methanol $(0.8: 1: 2, v / v / v)$. The supernatants were then split into two phases. The lipid-containing phase was passed through a column packed with $2 \mathrm{~g}$ of anhydrous $\mathrm{Na}_{2} \mathrm{SO}_{4}$, dried under $\mathrm{N}_{2}$, dissolved in $2 \mathrm{ml}$ of chloroform and transferred to a clean glass tube. The extracted lipids were separated into neutral lipids, glycolipids, and phospholipids by sequential elution from a silicic acid chromatographic column with chloroform, acetone, and methanol, respectively. Phospholipids in the methanol fraction were subjected to mild alkaline methanolysis. Peak areas of the fatty acid methyl esters (FAMEs) were quantified by adding methyl nonadecanoate as the internal standard. To remove lipid contaminants all glassware used was heated overnight at $400{ }^{\circ} \mathrm{C}$. According to Bååth's (2003) separate method, the fatty acids $18: 1 \omega 9$ and 18:2 $\omega 6$ were considered to be mainly of fungal origin, and the following fatty acids were considered to be of bacterial origin: i-14:0, i-15:0, a-15:0, i-16:0, 10-Me-16:0, br17:0, i-17:0, a-17:0, tuberculostearic acid (10-Me-18:0),

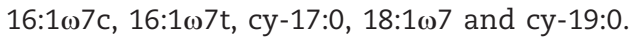

\subsection{Data analysis}

Principal component analysis was performed on the entire PLFA data set after $\log _{10}$ transformation. Data were subjected to three-way analysis of variance using the SPSS version 10.0 software package to determine the significance of soil phenanthrene concentration and AM inoculation with or without the surfactant as sources of variation. Comparison of means was made by calculation of least significant differences (LSD) at the $5 \%$ level.

\section{Results}

\subsection{Mycorrhizal root colonization and plant biomass}

Mycorrhizal root colonization and dry biomass of alfalfa after growth for 60 days are presented in Table 1. Roots of uninoculated plants remained uncolonized. Mycorrhizal colonization of the roots of inoculated plants decreased from $69.9 \%$ to $52.7 \%$ with increasing phenanthrene concentration. Addition of Triton X-100 decreased mycorrhizal colonization $(p<0.05)$, which varied from $64.9 \%$ to $51.0 \%$. Mycorrhizal colonization tended to decrease shoot dry weight $(p<0.001)$ while phenanthrene concentration did not significantly $(p>0.05)$ affect the dry weight of alfalfa shoots in any of the treatments. In contrast, mycorrhizal colonization did not significantly affect root dry weight $(p>0.05)$ while phenanthrene concentration did exert some effect on $(p<0.05)$ alfalfa root dry weight. Application of Triton X-100 significantly increased the biomass of both shoots and roots irrespective of phenanthrene application rate $(p<0.01)$. Plants had lower shoot yields and higher root dry weights in the presence of AM inoculation and application of Triton X-100 compared to the application of Triton X-100 alone with only one exception for the control treatment without phenanthrene addition to soil.

\subsection{Dissipation of phenanthrene in soils}

Fig. 1 shows the residual concentrations of phenanthrene in the rhizosphere and bulk soils. After plant harvest the phenanthrene concentrations in soil decreased markedly compared with the respective initial values. Because the residual contents of phenanthrene in soil reflect the degradation of the compound but also include the amounts adsorbed onto and taken up by plants, dissipation is more appropriate than degradation to describe the loss of phenanthrene in soil. The highest dissipation rate in rhizosphere soils was observed in the mycorrhizal treatment and occurred in bulk soils in the presence of AM inoculation plus Triton X-100 addition with
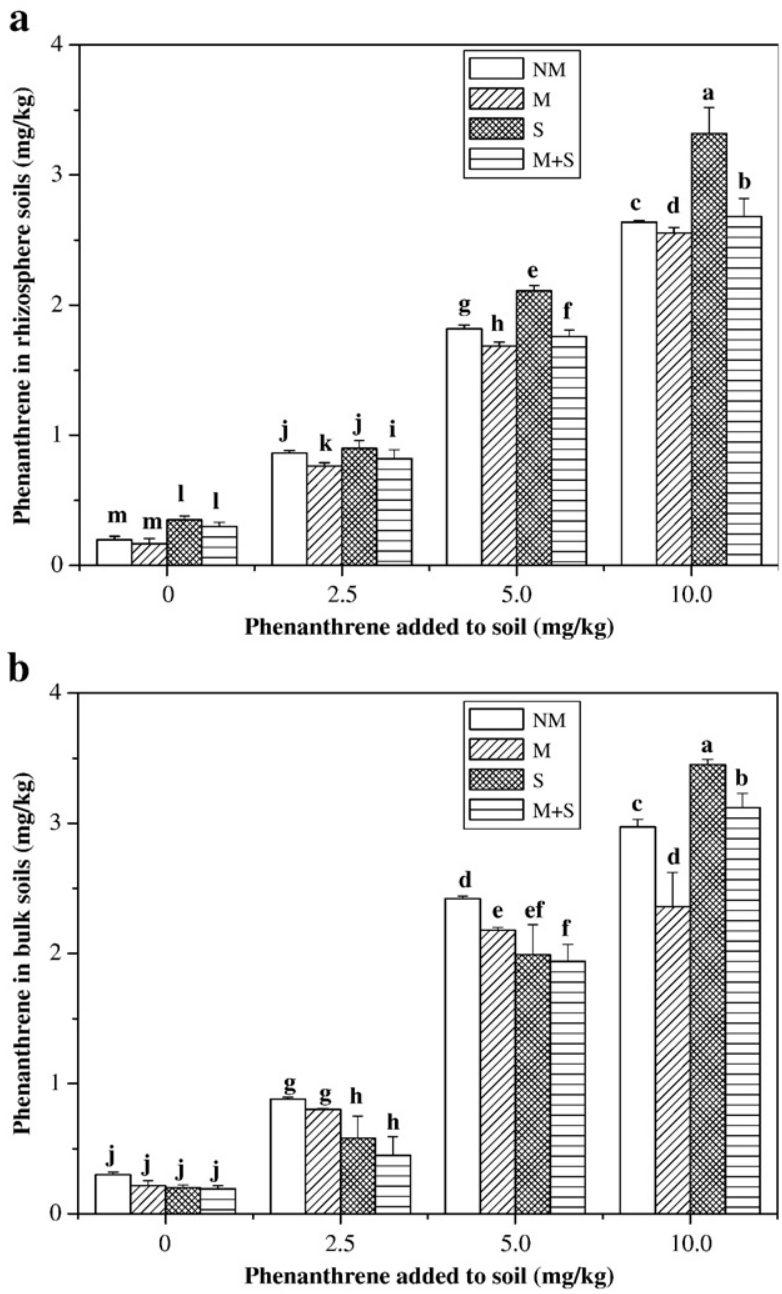

Fig. 1-Phenanthrene concentrations in (a) rhizosphere and (b) bulk soil. Means and standard errors $(n=3)$ are presented. NM, non-mycorrhizal ( $\square$ ); M, mycorrhizal (एu)); S, surfactant (ख); S+M, surfactant plus mycorrhizal ( Means with the same letter are not significantly different at the $5 \%$ level. 
the sole exception of the treatment with $10.0 \mathrm{mg} \mathrm{kg}^{-1}$ of phenanthrene in soil.

The residual phenanthrene concentration in soil was also compared among the treatments. The mycorrhizal treatments had significantly lower levels of phenanthrene in both the rhizosphere and bulk soils than did the non-mycorrhizal controls. Application of Triton X-100 resulted in a higher phenanthrene concentration in the rhizosphere soils and a lower concentration in the bulk soils compared to the treatments without application of Triton X-100 with the sole exception of phenanthrene application at $10.0 \mathrm{mg} \mathrm{kg}^{-1}$. The combination of AM inoculation and Triton X-100 application consistently enhanced the dissipation of phenanthrene in bulk soils and rhizosphere soils compared to the addition of Triton X-100 alone. Taking the bulk soil with the phenanthrene application concentration at $2.5 \mathrm{mg} \mathrm{kg}^{-1}$ as an example, decreases of $63.9 \%, 67.2 \%$ and $76.2 \%$ of the initial phenanthrene in bulk soil were observed for the non-mycorrhizal, mycorrhizal inoculation alone and Triton X-100 application alone treatments, respectively. A decrease of $81.4 \%$ in the bulk soil was attained in the treatment combining mycorrhizal inoculation with application of Triton X-100.

\subsection{Soil microbial biomass and community structure}

Twenty-two FAMEs were identified in the rhizosphere soils. The total PLFA concentration (66.0 to $154.7 \mathrm{ng} / \mathrm{g}$ dry weight for soil) showed marked variation in the rhizosphere soils in response to the different treatments and phenanthrene concentrations in soil as shown in Table 2. Soil microbial biomass increased with increasing phenanthrene concentration. AM inoculation and addition of Triton X-100 tended to decrease soil microbial biomass, measured as the total microbial PLFAs. Mycorrhizal inoculation plus Triton X-100 application diverged from other treatments (Fig. 2(a)). The corresponding loading values of the fatty acids were described with a PCA analysis (Fig. 2(b)). 18:109 increased along PC1 and showed that mycorrhizal treatment alone rather than mycorrhizal inoculation plus Triton X-100 application had proportionally more AM fungi. 10-Me-18:0, which has been reported to be common in Gram-positive bacteria, increased most along PC2, indicating that the microbial community under mycorrhizal inoculation plus Triton X-100 application had proportionally more Gram-positive bacteria. 18:1 107 decreased most along PC2, suggesting that treatments other than

Table 2 - PLFA indicative of total microbial, bacterial and fungal biomass in rhizosphere soil ( $\mathrm{nmol} / \mathrm{g}$ soil) ${ }^{\mathrm{a}}$ (mean \pm SE, $n=3$ )

\begin{tabular}{|c|c|c|c|c|}
\hline $\begin{array}{l}\text { Initial phenanthrene addition } \\
\mathrm{mg} \mathrm{kg}^{-1}\end{array}$ & Treatment & $\begin{array}{l}\text { Total microbial PLFA } \\
\text { (nmol/g) }\end{array}$ & $\begin{array}{l}\text { Bacterial PLFA } \\
(\mathrm{nmol} / \mathrm{g})\end{array}$ & $\begin{array}{l}\text { Fungal PLFA } \\
\text { (nmol/g) }\end{array}$ \\
\hline \multirow[t]{4}{*}{0} & Non-mycorrhizal & $95.7 \pm 12.4$ cdef & $44.6 \pm 10.2 \mathrm{~cd}$ & $11.0 \pm 3.2 b$ \\
\hline & Mycorrhizal & $85.8 \pm 10.5$ efg & $35.4 \pm 4.8 \mathrm{def}$ & $8.5 \pm 2.3 b c$ \\
\hline & Surfactant & $76.0 \pm 11.2 \mathrm{gh}$ & $40.6 \pm 3.7 \mathrm{cde}$ & $6.8 \pm 0.6 b c$ \\
\hline & $\begin{array}{l}\text { Mycorrhizal+ } \\
\text { surfactant }\end{array}$ & $66.0 \pm 7.6 \mathrm{hi}$ & $28.6 \pm 3.8 \mathrm{f}$ & $7.9 \pm 2.2 b c$ \\
\hline \multirow[t]{4}{*}{2.5} & Non-mycorrhizal & $113.12 \pm 12.1 b c$ & $47.0 \pm 2.1 \mathrm{c}$ & $10.8 \pm 2.8 b c$ \\
\hline & Mycorrhizal & $88.9 \pm 9.3 \mathrm{defg}$ & $35.8 \pm 5.6 \mathrm{def}$ & $7.4 \pm 3.5 b c$ \\
\hline & Surfactant & $80.2 \pm 7.9 \mathrm{fgh}$ & $32.5 \pm 6.4 \mathrm{def}$ & $6.6 \pm 3.7 b c$ \\
\hline & $\begin{array}{l}\text { Mycorrhizal+ } \\
\text { surfactant }\end{array}$ & $58.5 \pm 6.2 \mathrm{i}$ & $33.5 \pm 6.7$ ef & $6.9 \pm 2.4 b c$ \\
\hline \multirow[t]{4}{*}{5.0} & Non-mycorrhizal & $114.2 \pm 10.5 b$ & $48.9 \pm 8.9 c$ & $11.8 \pm 3.5 b$ \\
\hline & Mycorrhizal & $102.1 \pm 11.4 \mathrm{bcde}$ & $39.5 \pm 3.9 \mathrm{cde}$ & $9.5 \pm 3.8 b c$ \\
\hline & Surfactant & $76.8 \pm 8.0 \mathrm{gh}$ & $32.5 \pm 2.5$ aef & $8.6 \pm 2.9 b c$ \\
\hline & $\begin{array}{l}\text { Mycorrhizal+ } \\
\text { surfactant }\end{array}$ & $79.6 \pm 7.5 \mathrm{fgh}$ & $33.5 \pm 3.8 \mathrm{ef}$ & $10.3 \pm 3.1 b c$ \\
\hline \multirow[t]{4}{*}{10.0} & Non-mycorrhizal & $154.7 \pm 11.3 \mathrm{a}$ & $65.3 \pm 4.3 b$ & $16.9 \pm 2.7 \mathrm{a}$ \\
\hline & Mycorrhizal & $117.7 \pm 12.4 b$ & $46.8 \pm 4.8 \mathrm{c}$ & $11.3 \pm 4.3 b$ \\
\hline & Surfactant & $105.1 \pm 9.8 b c d$ & $28.8 \pm 3.6 f$ & $5.3 \pm 1.3 c$ \\
\hline & $\begin{array}{l}\text { Mycorrhizal+ } \\
\text { surfactant }\end{array}$ & $93.6 \pm 8.5 \mathrm{defg}$ & $38.8 \pm 4.9 \mathrm{cdef}$ & $10.9 \pm 0.8 b c$ \\
\hline \multicolumn{5}{|l|}{ Significance of: } \\
\hline Phenanthrene level & & $* * *$ & $* * *$ & * \\
\hline Inoculation & & $* * *$ & $* * *$ & ** \\
\hline Surfactant & & $* * *$ & $* * *$ & n.s. \\
\hline Phenanthrene level $\times$ inoculation & & n.s. & ** & n.s. \\
\hline Phenanthrene level ×surfactant & & n.s. & n.s. & n.s. \\
\hline Inoculation $\times$ surfactant & & n.s. & *** & * \\
\hline $\begin{array}{l}\text { Phenanthrene level } \times \text { inoculation } \times \\
\text { surfactant }\end{array}$ & & n.s. & * & n.s. \\
\hline \multicolumn{5}{|l|}{$\begin{array}{l}\text { *** Significant effect at } p<0.001 \text {. } \\
\text { ** Significant effect at } p<0.01 \text {. } \\
\text { * Significant effect at } p<0.05 \text {. } \\
\text { n.s., not significant. } \\
{ }^{\text {a }} \text { Means within each column wi }\end{array}$} \\
\hline
\end{tabular}



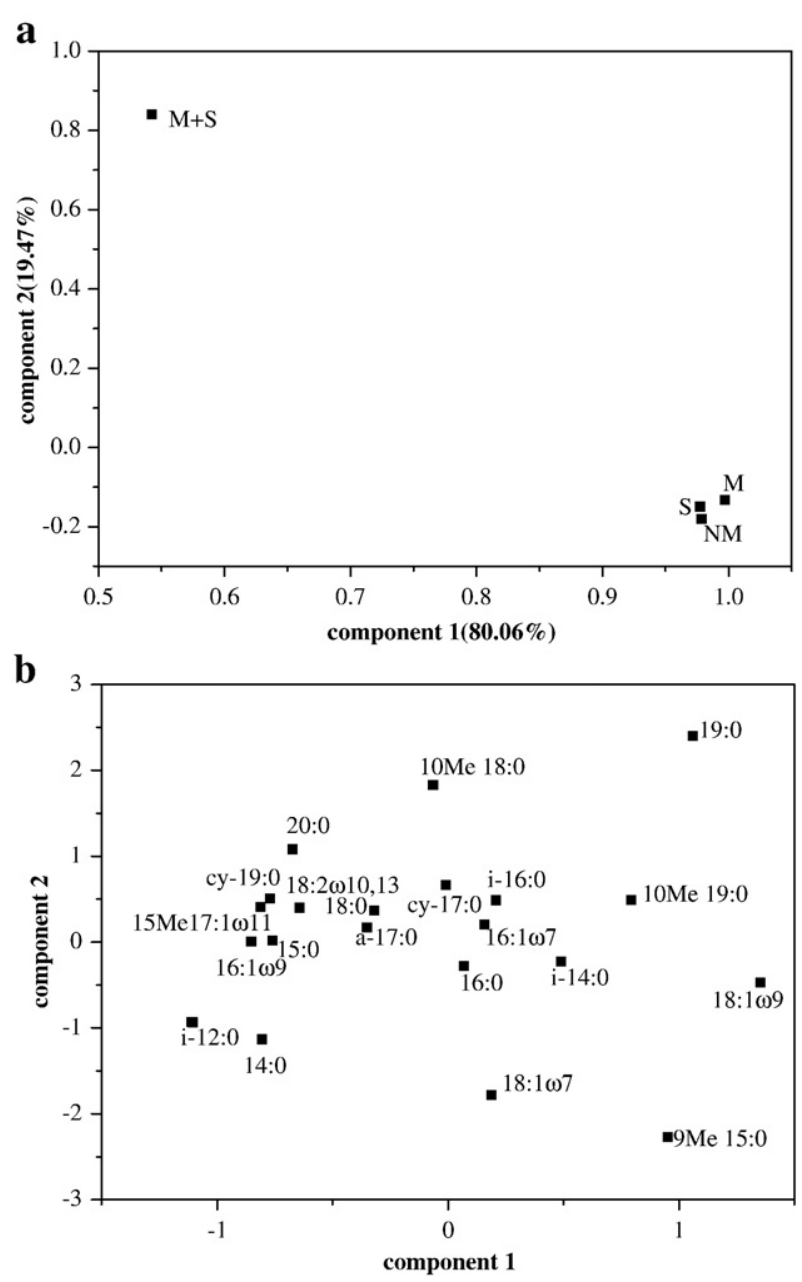

Fig. 2-(a) The phospholipid fatty acid patterns of different treatments (NM, non-mycorrhizal; M, mycorrhizal; S, surfactant; $\mathbf{S}+\mathrm{M}$, surfactant plus mycorrhizal). (b) Loadings of the individual PLFAs from the PCA of the PLFA data of principal components 1 and 2.

mycorrhizal inoculation plus Triton X-100 application had proportionally more Gram-negative bacteria.

\section{Discussion}

AM inoculation alone and combined with the addition of Triton X-100 had positive effects on the dissipation of phenanthrene in soil. Dissipation of organic contaminants from soil is often attributed to microorganisms living in the rhizosphere associated with plant roots (Mueller and Shann, 2006). We expected that mycorrhizal inoculation would stimulate soil microbial activity. However, contrary to our expectations, inoculation did not increase the microbial biomass (as shown in Table 2). A similar phenomenon was also observed by Joner et al. (2001) in their study on the interaction between mycorrhiza and PAHs in soil. Statistical analysis showed that within each phenanthrene concentration (except at $10.0 \mathrm{mg} \mathrm{kg}^{-1}$ ) the dissipation rate of phenanthrene in soil was positively correlated to the decrease in microbial counts when the treatments were compared to the non-mycorrhizal controls $(p<0.01)$. We therefore speculate that the lack of increase in soil microbial biomass in mycorrhizal treatments may be attributable to microbial phenanthrene degradation which may have depressed the soil microbial biomass. Another possible explanation is that mycorrhiza may have stimulated the growth of the specific microbial populations only, a conclusion supported by the results of the PLFA analysis which show that $18: 1 \omega 9$, indicative of fungi, increased in the mycorrhizal treatments.

After cropping, the residual concentrations of phenanthrene in soils decreased significantly (Fig. 1) and the decrease was further amplified by mycorrhizal inoculation at the $5 \%$ significance level although the mycorrhizal effect was quite small. The effects of Triton X-100 are particularly interesting. It has been reported that Triton X-100 can lead to an increase in the solubility of phenanthrene and pyrene (Cuypers et al., 2002). In the present study Triton $X-100$ decreased the residual concentrations of phenanthrene in the bulk soils while increasing the concentrations in the rhizosphere soils compared to the treatments without the addition of Triton X-100. Surfactant micelles offer a good hydrophobic environment to which the organic solutes can partition, which is likely to change the desorption behavior and result in the enhanced mobility and transportation of phenanthrene towards rhizosphere soil. Increased transport of phenanthrene towards rhizosphere soil thus results in the rhizosphere acting as a sink for phenanthrene. Although we did not find any evidence of toxic effects in the present study, surfactant amendment has been reported to have a toxic effect on the extraradical mycelium of AM fungi or the associated microflora (Joner et al., 2001), which may depress the degradation of phenanthrene in soil. The combination of increased transport and decreased degradation in the presence of Triton X-100 may have resulted in the higher phenanthrene levels observed in the rhizosphere soils.

\section{Conclusions}

The present study has demonstrated that the residual concentrations of phenanthrene in soils decreased significantly after transplanting. The presence of mycorrhiza consistently enhanced the dissipation of phenanthrene in both the bulk and rhizosphere soils irrespective of the amount of phenanthrene present. Addition of Triton X-100 increased the mobility and thereby the transport of phenanthrene from the bulk soil to the rhizosphere soil, resulting in a higher phenanthrene concentration in the rhizosphere soil.

The findings of this study provide preliminary evidence for the potential of AM inoculation and surfactant application in the decontamination of organic pollutants in soil. The results provide a reference value for phytoremediation of soil contaminated by phenanthrene and possibly also by other organic pollutants. However, detailed and comprehensive studies on the selection of plant species, AM fungi and surfactants will be required to establish effective remediation methods under field conditions. Furthermore, analysis of microbial biomass and characterization of soil microbial community confirm that the presence of AM fungi 
does not always result in an increase in soil microbial biomass. Further studies are therefore necessary to identify the role of specific microbial populations in the degradation of a given organic contaminant in soil in order to elucidate the mechanisms involved and explain the diverse effects observed of AM fungi on the degradation of organic contaminants.

\section{Acknowledgments}

This work was funded by the High Technology Research and Development Program of China (Project 2006AA06Z349) and the National Natural Science Foundation of China (Projects 20677072, 20621703 and 40730740).

\section{R E F E R E N C E S}

Bååth E. The use of neutral lipid fatty acids to indicate the physiological conditions of soil fungi. Microb Ecol 2003;45:373-83.

Binet P, Portal JM, Leyval C. Fate of polycyclic aromatic hydrocarbons (PAH) in the rhizosphere and mycorrhizosphere of ryegrass. Plant Soil 2000;227:207-13.

Chen BL, Johnson EJ, Chefetz B, Zhu LZ, Xing BS. Sorption of polar and nonpolar aromatic organic contaminants by plant cuticular materials: role of polarity and accessibility. Environ Sci Technol 2005;39:6138-46.

Cuypers C, Pancras T, Grotenhuis T, Rulkens W. The estimation of PAH bioavailability in contaminated sediments using hydroxypropyl- $\beta$-cyclodextrin and Triton X-100 extraction techniques. Chemosphere 2002;46:1235-45.

Genney DR, Alexander IJ, Killham K, Meharg AA. Degradation of the polycyclic aromatic hydrocarbon (PAH) fluorene is retarded in a Scots pine ectomycorrhizosphere. New Phytol 2004;163:641-9.

Giovannetti M, Mosse B. An evaluation of techniques for measuring vesicular arbuscular mycorrhizal infection in roots. New Phytol 1980;84:489-500.

Joner EJ, Leyval C. Rhizosphere gradients of polycyclic aromatic hydrocarbon (PAH) dissipation in two industrial soils and the impact of arbuscular mycorrhiza. Environ Sci Technol 2003;37:2371-5.

Joner EJ, Johansen A, Loibner AP, dela Cruz MA, Szolar OHJ, Portal JM, et al. Rhizosphere effects on microbial community structure and dissipation and toxicity of polycyclic aromatic hydrocarbons (PAHs) in spiked soil. Environ Sci Technol 2001;35:2773-7.

Joner EJ, Leyval C, Colpaert JV. Ectomycorrhizas impede phytoremediation of polycyclic aromatic hydrocarbons (PAHs) both within and beyond the rhizosphere. Environ Pollut 2006;142:34-8.

Mueller KE, Shann JR. PAH dissipation in spiked soil: impacts of bioavailability, microbial activity, and trees. Chemosphere 2006;64:1006-14.

Wilson SC, Jones KC. Bioremediation of soil contaminated with polynuclear aromatic hydrocarbons (PAHs): a review. Environ Pollut 1993;81:229-49.

Zhou WJ, Zhu LZ. Solubilization of polycyclic aromatic hydrocarbons by anionic-nonionic mixed surfactant. Colloids Surf A 2005;255:145-52.

Zhu LZ, Chen BL, Tao S, Chiou CT. Interactions of organic contaminants with mineral-adsorbed surfactants. Environ Sci Technol 2003;37:4001-6. 